\title{
The main causes of blindness and low vision in school for blind
}

\author{
As principais causas de cegueira e baixa visão \\ em escola para deficientes visuais
}

Abelardo Couto Junior ${ }^{1}$, Lucas Azeredo Gonçalves de Oliveira²

\begin{abstract}
Objective: Identify and analyze the main causes of blindness and low vision in school for blind. Methods: One hundred sixty-five medical records of visually impaired students were reviewed in an institution specialized in teaching the blind, treated between august 2013 and may 2014. The variables analyzed were age, sex, visual acuity, primary and secondary diagnoses, treatment, optical prescription features and prognosis. Results: 165 students were evaluated, 91 students (55\%) are legally blind and only 74 (45\%) of the students are classified as low vision. The main causes of blindness were: retinopathy of prematurity (21\%), optic nerve atrophy (18\%), congenital glaucoma (16\%), retinal dystrophy (11\%) and cancer (8\%). The causes of low vision were: congenital cataract (18\%), congenital glaucoma (15\%) and retinochoroidal scarring (12\%). Conclusion: The main causes of blindness and low vision in the Benjamin Constant Institute are from preventable diseases.
\end{abstract}

Keywords: Blindness; Low vision; Visual acuity; Child; Health school

\section{RESUMO}

Objetivo: Identificar e analisar as principais causas de cegueira e baixa visão em escola para deficientes visuais. Métodos: Foram revisados 165 prontuários de alunos portadores de deficiência visual em instituição especializada no ensino de cegos, atendidos no período de agosto de 2013 a maio de 2014. As variáveis analisadas foram: idade, gênero, acuidade visual, diagnóstico principal e secundário, tratamento, recursos ópticos prescritos e prognóstico. Resultados: Dos 165 alunos avaliados, 91 alunos (55\%) são legalmente cegos e apenas 74 (45\%) dos alunos são enquadrados como baixa visão. As principais causas identificadas foram: retinopatia da prematuridade $(21 \%)$, atrofia de nervo óptico (18\%), glaucoma congênito (16\%), distrofias retinianas (11\%) e neoplasias ( $8 \%)$. As causas de baixa visão foram: catarata congênita (18\%), glaucoma congênito (15\%) e cicatriz de retinocoroidite $(12 \%)$. As causas de cegueira evitáveis (preveníveis ou tratáveis) no estudo perfizeram um total de 52\%.Conclusão: As principais causas de cegueira e baixa visão nos alunos do Instituto Benjamin Constant são por doenças evitáveis.

Descritores: Cegueira; Baixa visão; Acuidade visual; Escolar; Criança; Saúde escolar;

'Faculdade de Medicina de Valença; Instituto Benjamin Constant; Pontifícia Universidade Católica, Rio de Janeiro, RJ, Brazil. ${ }^{2}$ Instituto Benjamin Constant, Rio de Janeiro, RJ, Brazil.

Study conducted at Instituto Benjamin Constant, Rio de Janeiro, RJ, Brazil.

The authors declare no conflicts of interests.

Received for publication 17/06/2015 - Accepted for publication 16/09/2015

Rev Bras Oftalmol. 2016; 75 (1): 26-9 


\section{INTRODUCTION}

$\mathbf{C}$ hildhood blindness is a debilitating comorbidity that affects millions of children in Brazil and in the world.

According to estimates by publication of the World Health Organization (WHO) $)^{(1)}$ in 2002, there were nearly 36.9 million blind people in the world. Approximately two thirds of them are blind from preventable causes ${ }^{(2)}$, and about 1.4 million are under 15 years of age. Of children with blindness, 70 to $80 \%$ die during the first years of life as a result of illnesses associated to their visual impairment.

The $\mathrm{WHO}^{(1)}$ defines by means of the International Statistical Classification of Diseases, Injuries and Causes of Death, 10th revision (ICD-10) as legal blindness the visual acuity below 20/ 400 or the visual field below 10 degrees, and as low vision the visual acuity below $20 / 60$ or the visual field below 20 degrees in the better eye.

About $20 \%$ of school-age children have some type of eye disorder of varying causes, linked to biological, social and environmental factors. The delay in diagnosis causes damage in academic performance and socialization of the child, and can harm future job opportunities. This situation may even pose an economic burden on society, requiring early action of identification and appropriate treatment ${ }^{(3)}$.

The main causes of low vision in children reported in the literature are the refractive errors that if left untreated can lead to blindness and bring not only to Brazil and the rest of Latin America but worldwide great economic and psychosocial impact. ${ }^{(4)}$

Due to the rapid growth and development of the eye, the child is more vulnerable to visual disorders. The impairment of ocular health represents an important inhibitor to the child's development, with the potential of having sequels in adulthood.(5)

The objective of this study is to identify the main causes of blindness and low vision in a specialized school for the blind.

\section{Methods}

Was conducted an observational transverse study based on the data obtained from 165 medical records of 205 students at Benjamin Constant Institute (IBC), Urca-RJ, from the second to the ninth grade of elementary school, examined in the period from August 2013 to May 2014 by 12 residents in ophthalmology.

The variables analyzed were: age, gender, school grade, best visual acuity with or without correction, optical resource used, primary and secondary diagnosis, family history of blindness, clinical treatment and previous surgery, prognosis and visual classification.

Visual acuity was assessed in accordance with the Snellen chart in all students, and the visual classification was made according to the $\mathrm{WHO}^{(1)}$ as legal blindness the visual acuity below $20 / 400$ or the visual field below 10 degrees, and as low vision the visual acuity below $20 / 60$ or the visual field below 20 degrees in the better eye.

A complete eye examination was made in all students assessed, including biomicroscopy and eye fundus. The data was recorded in a re-enrollment form attached to the medical record and later analyzed according to the study criteria. The exclusion criteria of the study was the presence of incomplete data in the re-enrollment form which accounted for 40 medical records.

\section{ResUlts}

Based on the analysis of the data collected, the age of the students ranged from 8 to 25 years, being $59 \%$ males and $41 \%$ females. Of the 165 students analyzed, only 67 made use of optical resources, and the most used ones were glasses, reading bar, hand-held magnifier and large font, respectively, according to the table 1 .

Table 1

Number of students using optical resources

\begin{tabular}{lc}
\hline Optical resources & N \\
\hline Glasses & 50 \\
Reading bar & 5 \\
Hand-held magnifier & 3 \\
Hand-held magnifier + Reading bar & 4 \\
Large font & 2 \\
Glasses + Hand-held magnifier & 2 \\
Glasses + Reading bar & 1 \\
Do not use & 98 \\
\hline
\end{tabular}

The visual acuity of students varies from no light perception to acuity of 20/40 according to the Snellen chart, shown in Table 2

Table 2

Visual acuity of IBC students with and without correction

\begin{tabular}{lcc}
\hline & $\begin{array}{c}\text { Visual acuity } \\
\text { without correction }\end{array}$ & $\begin{array}{c}\text { Visual acuity } \\
\text { with correction }\end{array}$ \\
\hline No light perception & 25 & 25 \\
Light perception & 21 & 21 \\
Perception of figures & 16 & 16 \\
$<20 / 400$ & 43 & 23 \\
$20 / 400$ & 7 & 5 \\
$20 / 320$ & 8 & 8 \\
$20 / 250$ & 11 & 13 \\
$20 / 200$ & 18 & 9 \\
$20 / 160$ & 6 & 9 \\
$20 / 125$ & 3 & 7 \\
$20 / 100$ & 4 & 12 \\
$20 / 80$ & 0 & 6 \\
$20 / 60$ & 1 & 6 \\
$20 / 50$ & 1 & 1 \\
$20 / 40$ & 1 & 4 \\
\hline
\end{tabular}

Students who present vision 20/60, 20/50 and 20/40 with better correction have visual field below 20 degrees in the better eye.

Only $21 \%$ of students have history of family blindness. In the sample analyzed, $54 \%$ of the students were not subjected to treatments prior to enrollment at the Benjamin Constant Institute, whereas $85 \%$ of patients receiving previous treatment underwent surgery, and $25 \%$ had clinical treatment. According to the sample of study, $55 \%$ are classified as legal blindness and $45 \%$ as low vision.

The causes of avoidable blindness (preventable or treatable) in the study accounted for $52 \%$, and preventable pathologies were retinopathy of prematurity, congenital glaucoma, congenital cataracts, retinochoroiditis scar, retinal detachment and congenital rubella. 
The main cause of blindness in the IBC was retinopathy of prematurity followed by atrophy of the optic nerve, and the third cause is congenital glaucoma. The main cause of low vision was congenital cataracts, followed by congenital glaucoma and retinochoroiditis scar, as shown in table 3 .

Table 3

Primary diagnosis of blindness and low vision of students in the elementary school at IBC

\begin{tabular}{|c|c|c|c|c|}
\hline Primary diagnosis & Blind students & $\mathbf{N}(\%)$ & Alunos com baixa visão & $\mathbf{N}(\%)$ \\
\hline Retinopathy of prematurity & 19 & 21 & 4 & 5 \\
\hline Optic nerve atrophy & 16 & 18 & 6 & 8 \\
\hline Congenital glaucoma & 15 & 16 & 11 & 15 \\
\hline Retinal dystrophy & 10 & 11 & 4 & 5 \\
\hline Neoplasia & 7 & 8 & 1 & 1 \\
\hline Congenital cataracts & 6 & 7 & 13 & 18 \\
\hline Retinochoroiditis scar & 5 & 5 & 9 & 12 \\
\hline Change of the eye bulb & 4 & 4 & 1 & 1 \\
\hline Undiagnosed & 4 & 4 & 4 & 5 \\
\hline Aniridia & 2 & 2 & 5 & 7 \\
\hline Retinal detachment & 2 & 2 & 0 & 0 \\
\hline Congenital rubella & 1 & 1 & 0 & 0 \\
\hline Albinism & 0 & 0 & 8 & 11 \\
\hline Coloboma & 0 & 0 & 3 & 4 \\
\hline Marfan syndrome & 0 & 0 & 2 & 3 \\
\hline Congenital cytomegalovirus & 0 & 0 & 1 & 1 \\
\hline Keratoconus & 0 & 0 & 1 & 1 \\
\hline Eye trauma & 0 & 0 & 1 & 1 \\
\hline Total & 91 & 100 & 74 & 100 \\
\hline
\end{tabular}

According to the sample assessed, only 58 students had secondary diagnoses, and the most prevalent was retinal detachment, followed by congenital cataract and retinoblastoma, as shown in table 4

Table 4

Secondary diagnosis of IBC students

\begin{tabular}{|c|c|c|}
\hline & $\begin{array}{c}\text { Students with } \\
\text { secondary } \\
\text { diagnosis }\end{array}$ & $\mathbf{N}(\%)$ \\
\hline Retinal detachment & 12 & 20 \\
\hline Congenital cataracts & 9 & 15 \\
\hline Retinoblastoma & 7 & 12 \\
\hline Nystagmus & 4 & 6,8 \\
\hline Optic nerve atrophy & 4 & 6,8 \\
\hline Microphthalmos & 4 & 6,8 \\
\hline Aniridia & 3 & 5,1 \\
\hline Retinitis Pigmentosa & 2 & 3,4 \\
\hline Stargardt disease & 2 & 3,4 \\
\hline Secondary glaucoma & 1 & 1,7 \\
\hline Congenital corneal opacity & 1 & 1,7 \\
\hline Degenerative myopia & 1 & 1,7 \\
\hline Leber congenital amaurosis & 1 & 1,7 \\
\hline Ganglioglioma & 1 & 1,7 \\
\hline Encephalopathy & 1 & 1,7 \\
\hline Anoftalmia & 1 & 1,7 \\
\hline Peters syndrome & 1 & 1,7 \\
\hline Retinochoroiditis scar & 1 & 1,7 \\
\hline Congenital malformation & 1 & 1,7 \\
\hline Congenital syphilis & 1 & 1,7 \\
\hline Total & 58 & 100 \\
\hline
\end{tabular}

\section{Discussion}

There was no significant difference between the gender: $59 \%$ males X $41 \%$ females.

The use of optical resources is not yet widespread among the blind students, as only $40 \%$ of students make use of any optical resources.

As it is a school specialized in teaching people with severe blindness, the Benjamin Constant Institute does not reflect the outlook of childhood visual impairment in Rio de Janeiro. Of the 165 students evaluated, 91 students $(55 \%)$ are legally blind and only $74(45 \%)$ students are classified as having low vision.

In pioneering work done in a school for the blind in Brazil, Leite Filho et al. ${ }^{(6)}$ analyzed 600 students enrolled in the IBC between 4 and 20 years of age, describing a prevalence of: $19.6 \%$ of cataract (congenital + complicated), $19.5 \%$ of leukomas, $15.1 \%$ of retinal degenerations, $12.1 \%$ of congenital glaucoma and $12 \%$ of optic nerve atrophy as causes of blindness. Despite the 44 years of difference between the works, it is possible to see that optic nerve atrophy, congenital glaucoma, congenital cataract and retinal dystrophies still have high prevalence in this population under study.

Conti et al., ${ }^{(7)}$ described the causes of blindness assessing 477 blind adults and children from 18 institutions (schools, shelters and workshops) from the state of Guanabara and found: $20.3 \%$ of glaucoma, $20.1 \%$ of corneal opacities, $17 \%$ of cataract and $16.9 \%$ of retinal and optic nerve diseases. Due to the heterogeneity of the sample it is difficult to have a comparative study with the present research.

Couto Jr et al. in a previous study ${ }^{(8)}$ with no visually impaired population, identified $1.11 \%$ of ophthalmopathies, of which retinochoroiditis $0.17 \%$, cataract $0.22 \%$ and a prevalence 
of amblyopia of $2.00 \%$, reflecting a different overview of ophthalmopathy in Rio de Janeiro.

The difficult access to specialized medicine and the lack of information to patients are realities to consider in Brazil. Based on the analysis of the data from this study, $54 \%$ of patients did not receive treatment prior to enrollment in the Benjamin Constant Institute.

Hereditary diseases, damage to the optic nerve and visual pathways are the main causes of blindness and low vision in developed countries ${ }^{(4,9)}$ Developing countries have more cases associated to infection and nutritional deficiencies such as measles, neonatal ophthalmia, cataract due to rubella and xerostomia by vitamin A deficiency. However, there are other significant causes of blindness as congenital cataract, congenital glaucoma, hereditary retinal dystrophies, and congenital abnormalities, which keeps its prevalence both in developed countries and in developing countries.

Brazil has characteristics similar to developing countries, but studies in São Paulo and Salvador ${ }^{(4)}$ have shown that the main causes of blindness are congenital glaucoma, retinopathy of prematurity, rubella, congenital cataract and congenital toxoplasmosis, in contrast to previous data from the literature ${ }^{(10,11)}$ pointing out as main causes of childhood blindness in Brazil vitamin A deficiency, trachoma, measles and onchocerciasis.

The main causes of child blindness may vary according to the region assessed. In this study, retinopathy of prematurity was identified as a main cause of blindness, accounting for $21 \%$ of cases, followed by atrophy of the optic nerve, congenital glaucoma, retinal dystrophies and neoplasms. The main cause of low vision was congenital cataracts with $18 \%$ of cases, followed by congenital glaucoma and retinochoroiditis scar.

Regardless of the cause, childhood blindness brings serious harms to children and their family for life, influencing the personal, educational, social and employment perspectives.

Preventing childhood blindness remains a major challenge. The elimination of preventable and treatable blindness in children is a priority for WHO by the year 2020. Therefore, identifying the epidemiology is key to prevention.

\section{REFERENCES}

1. Resnikoff S, Pascolini D, Etya'ale D, Kocur I, Pararajasegaram R, Pokharel GP, MariottI SP. Global data on visual impairment in the year 2002. Bull WHO. 2004; 82(11): 844-51.

2. Kara-José N, Almeida GV, Arieta CEL, Araújo JS, Becgara SJ, Oliveira PR. Causas de deficiência visual em crianças. Bol Sanit Panam. 1994;97(5): 405-12.

3. Oliveira CA , Hisatomi KS, Leite CP, Schellini AS, Padovani CR, Padovani CRP. Erros de refração como causas de baixa visual em crianças da rede de escolas públicas da regional de Botucatu - SP. Arq Bras Oftalmol. 2009;72(2):194-8.

4. Brito PR, Veitzman S. Causas de cegueira e baixa visão em crianças. Arq Bras Oftalmol. 2000;63(1):49-54.

5. Rocha, MN, Ávila MP, Isaac DL, Mendonça LS, Nakanishi L, Auad LJ.Prevalência de doenças oculares e causas de comprometimento visual em crianças atendidas em um Centro de Referência em Oftalmologia do centro-oeste do Brasil. Rev Bras Oftalmol. 2014;73(4):225-9.

6. Leite Filho LA, Morizot - Kunihiro Nitta. Aspectos da cegueira na infância em nosso meio. Rev Bras Oftalmol. 1971; 30(4):413-5.

7. Conti PR, et al. Causas de cegueira em cegos assistidos por instruções no Estado da Guanabara. Rev Bras Oftalmol. 1975; 34(3):395-8.
8. Couto Jr AS, Pinto GR, Oliveira DA, Holzmeister D, Portes AL, Neurauter R, Portes AJ. Prevalência das ametropias e oftalmopatias em crianças pré-escolares e escolares em favelas do Alto da Boa Vista, Rio de Janeiro, Brasil. Rev Bras Oftalmol. 2007; 66(5):304-8.

9. Sociedade de Pediatria de São Paulo. Recomendações Sociedade de Pediatria de São Paulo, Atualização de condutas em pediatria, 49. São Paulo: Sociedade de Pediatria de São Paulo; 2009. [citado 2014 Ago 22]. Disponível em: www.spsp. org.br/downloads/ rec_49_cegueira.pdf

10. Oliveira PR. Causas de cegueira na infância. Arq Bras Oftalmol. 1992;55(4):174-5.

11. Simmons WK. Xerophthalmia and blindness in northeast Brazil. Am J Clin Nutr. 1976;29(1):116-22.

\section{Corresponding author:}

Abelardo Couto Júnior

Phone: 21996263476

E-mail: coutojras@ig.com.br 